\title{
Refugee Self-Management and the Question of Governance
}

\author{
Jennifer Hyndman
}

\begin{abstract}
The author considers the organization of refugee camps as "communities" or "institutions" and takes the position that refugee camps are too institutional in character to establish or maintain traditional community-based supports. The implications that such definitions hold for camp governance and for the situation of refugee women, in particular, are discussed and the problematics for refugee self-governance are focused on the complex organizational boundaries drawn between UNHCR, NGOs and the camp refugees. A gendered framework is pivotal to the analyses.
\end{abstract}

\section{Précis}

L'auteure examine l'organisation des camps de réfugié(e)s en "communautés" ou "institutions", et soutient que les camps de réfugié(e)s sont trop typiquement "institutionnels" pour permettre le développement de structures réellement communautaires. Elle présente l'impact que de telles définitions peuvent avoir sur la gestion des camps, et particulièrement sur les réfugiées. Cet impact est discuté dans le cadre des

Jennifer Hyndman is Assistant Professor of Geography, Arizona State University West, Phoenix, Arizona, USA.

The author would like to acknowledge the financial support of the Centre for Refugee Studies at York University, the International Deoelopment and Research Centre, and the Social Science and Humanities Research Council of Canada-all of which provided the basis for an extensive research program. I am also grateful for the cooperation and assistance of staff at the United Nations High Commissioner for Refugees, at headquarters in Geneoa, at Branch Office Nairobi, and in the Dadaab camps near the Kenya-Somalia border. A draft of this paper was presented to the Canadian Association of Geographers Annual Conference, Montréal, June 4, 1995. Preliminary findings were presented at the 'Gender \& Migration Symposium" organized by the International Geographical Union in Pretoria, South Africa, April 9-13, 1995. problématiques de l'autonomie des réfugié(e)s en ce qui a trait aux frontières internationales établies entre le Haut Commissariat aux réfugié(e)s des Nations Unies, les organismes nongouvernementaux et les camps de réfugié(e)s. La sexualisation est au coeur de cette analyse

Refugee studies often focus on a specific place of asylum or on a particular refugee population rather than on the central sites of economic and political power, namely the well-endowed international agencies that organize refugees and camp operations. In conjunction with a variety of specialized non-governmental organizations (NGOs), the United Nations High Commissioner for Refugees (UNHCR) is the main international agency responsible for coordinating, monitoring, and providing protection and assistance to refugees. Accordingly, the case can be made for "studying up" (Abu-Lughod 1991; Pred and Watts 1992): that is, examining critically the culture, practices, and policies of powerful humanitarian organizations rather than the people they serve.

Based on research in Geneva and Kenya carried out in 1994-95, this article first reviews UNHCR policies that aim to incorporate gender and cultural difference. Such policies provide the parameters within which non-governmental organizations, working with and for UNHCR in refugee camps, can operate. In the second section, I introduce the example of a particular NGO initiative in Kenyan camps implemented under the aegis of UNHCR and provide constructive criticism relating to its practical and political implications. Two related questions are discussed: "is a refugee camp a community or an institution?"; and "what are the gender implications for refugees?"

These questions are generated from the approach of studying up and from the subsequent analysis of management practices of refugee relief agencies. It addresses issues of gender, feminist policy, and cultural politics in refugee work. UNHCR, for example, has based many of its recent policies, guidelines, and program requirements pertaining to women on selected community development principles (Overholt et al. 1985). Some of these principles are relevant and important to equitable planning and participation in refugee situations. Others employ the rhetoric of community because it is popular, acceptable, and politically strategic in humanitarian donor circles. I argue here that community is part of a strategic discourse which consolidates the institutional power of refugee relief organizations and that "tendencies toward forming a singular network derive from the emergent need to institutionalize social returns" (Mann 1986, 14).

This paper contends that a refugee camp differs from a community in several important ways. Prima facie refugees, involuntary migrants who are recognized by UNHCR but do not meet the Convention definition, lack legal and often physical protection. These "second-rate" refugees, whose status is determined on a group rather than an individual basis, are usually dependent on humanitarian agencies for their basic needs, having little access to resources, jobs, or other livelihoods. Prima facie refugees often face stigma and discrimination in the host country, this being especially true of Somalis in Kenya where historically they have been discriminated against and harassed by Kenyan authorities.

In Kenyan refugee camps, any reformulation of power and status is relational and involves at least three groups: the local Kenyan population, the refugees, and the humanitarian international. This last group refers to the cadre of international professionals working in relief organizations 
who form a cosmopolitan, liberal elite (African Rights 1994, 9). The vast majority-over ninety percent-of refugees in the Dadaab camps located near the Kenya-Somalia border are Somalis (see map). Just as cultures are hierarchically situated when they interact with one another, members of these three groups have different political statuses and differential power to influence refugee camp operations. I have argued elsewhere (Hyndman 1996) that camps are sites of neo-colonial power relations where refugees are counted, their movements monitored and mapped, their daily routines disciplined and routinized by the institutional machinery of refugee relief agencies. Proposals for change in such environments are rarely gender-neutral; culturally specific gender divisions of labour and Western-based community development principles locate women in a contradictory range of subject positions.

\section{Gendered Cultures at UNHCR}

Since the late 1980s, a number of different analyses of gender have been developed as part of UNHCR's policy on refugee women. Most address the specific problems and discrimination refugee women face and thus follow the paradigm of liberal feminism. Emphasis is on equality, integration, and mainstreaming as being the most salient features. The underlying principles of the policy include "the integration of the resources and needs of refugee women into all aspects of programming, rather than creating special women's projects" (UNHCR 1990, 4). Furthermore, "becoming a refugee affects men and women differently and that effective programming must recognize these differences" in a culturally appropriate manner (ibid., 5). Such gender analysis often remains intact as policy, but as I will illustrate, implementations and conflicting professional approaches introduce difficulties.

The "People-Oriented Planning Process" (Anderson, Brazeau, and Overholt 1992), or POP as it is called, is a euphemistic title referring to a gen- der analysis integrated with community planning. Both POP and the "Guidelines on the Protection of Refugee Women" (UNHCR 1991) identify the physical spaces in which refugee women live as important for reasons of safety as well as to ensure equitable access to basic services and supplies. UNHCR recognizes that women refu- gees are often more vulnerable in camp situations because family protection and traditional authority structures break down and economic support is less available (UNHCR 1993). Camp layout and location are acknowledged as important factors at a general level; historical context, geopolitical factors, and cultural differences are left for the

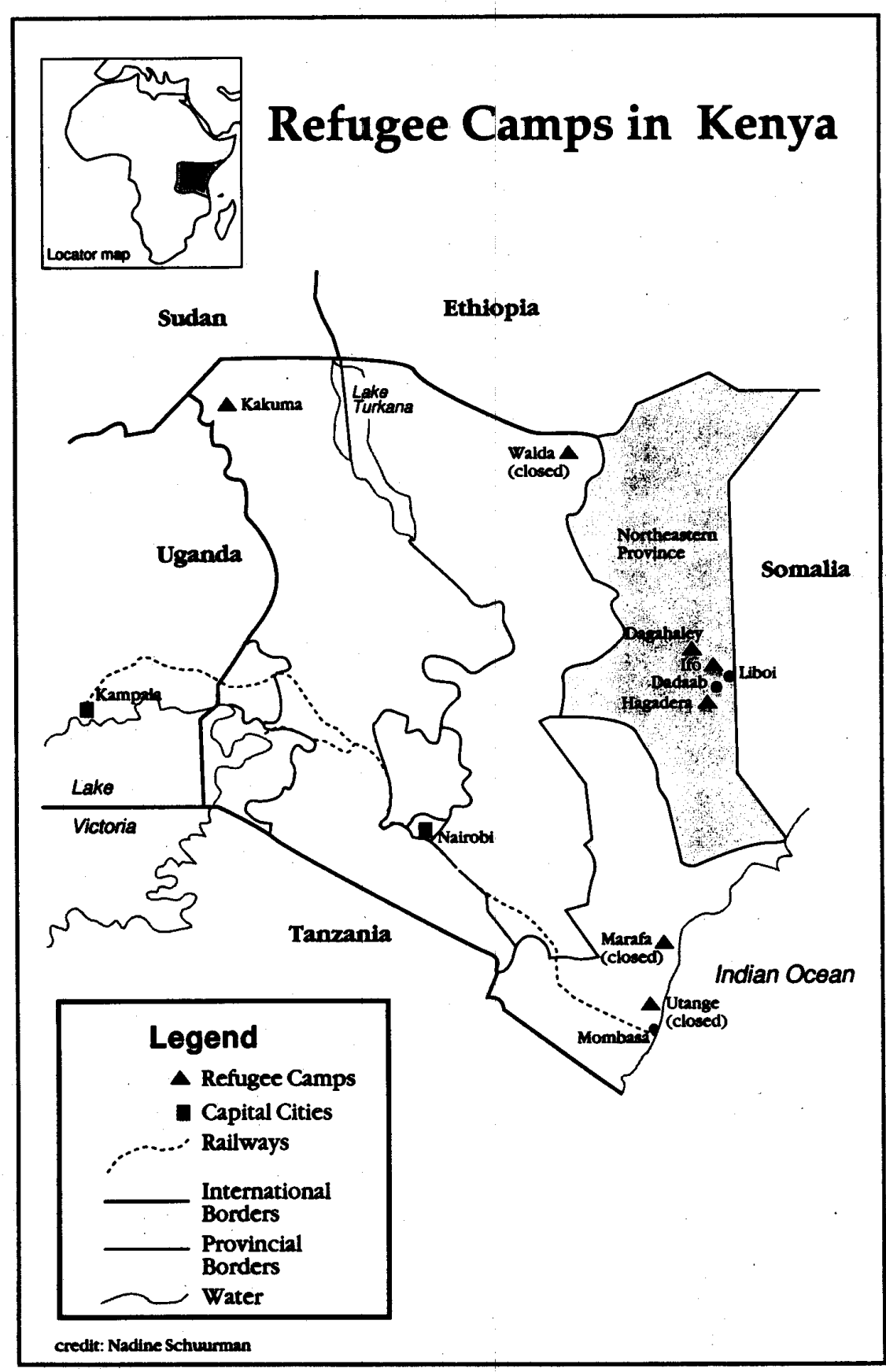

Refuge, Vol. 16, No. 2 (June 1997) 
field workers to fill in once placed in the field. UNHCR guidelines are, then, generic policies, universally applicable, in theory to all refuge situations. This liberal sensibility, which acknowledges cultural diversity and incorporates local conditions to some extent, remains part of a Westernbased system of knowledge. In practice, cultural politics, host government response to refugees, and emerging political events cannot be accounted for a priori.

UNHCR policy pertaining to refugee women generally subordinates cultural differences to gender differences. On paper, the organization's various initiatives are a reasonably impressive collation of feminist analyses and recommended action. They include liberal, radical, and socialist sensibilities which address issues of discrimination, violence, and systemic material inequality respectively (UNHCR May and October 1993). The lack of attention paid to cultural differences and to the hierarchical positioning of cultures (Gupta and Ferguson 1992 ) in the camps is a major lacuna in UNHCR programming. On one hand, the frequent use of the category "woman" by UNHCR as a primary organizing concept essentializes and reinforces the primacy of gender over ethnic, clan, and other relations of difference. On the other, this usage seems contrary to the basic liberal principle articulated in UNHCR policy, namely "mainstreaming and integration." While certain groups of women refugees are listed as vulnerable and requiring special assistance in the camps (UNHCR 1994), other planning documents insist that women be equal partners in decision-making processes and that they have equitable access to services and resources (UNHCR 1990, 1991; Anderson, Brazeau, and Overholt 1992). The contradictions and complexities of refugee programming at UNHCR with respect to gender and cultural differences thus begin to emerge.

In no way can UNHCR's approach to women refugees be viewed as coherent, unitary, or internally consist-

ent. Despite policies that consistently underscore, integrationist approaches and the mainstreaming of women, professional approaches differ dramatically within the organization. This was confirmed in interviews with the Senior Coordinator for Refugee Women at UNHCR in Geneva. The Coordinator underlined the complexities of introducing an "empowerment approach" in delivering programs for refugee women in an environment that had been dominated for decades by a traditional social welfare approach, focusing on vulnerabilities and with an emphasis on traditional culture rather than universal human rights. While the renaming of social services to community services signals a commitment to, and a move towards, communitybased approaches at UNHCR, changes in attitude among staff members and implementing partners will take some time to evolve.

Some critics maintain that UNHCR's policies on women are weak; they avoid the use of gender per $s e$ and invoke changes that are "too basic." The Senior Coordinator for Refugee Women points out that:

\begin{abstract}
Bilateral development agencies such as CIDA have many years of experience in developing and implementing women in development and gender policies and programmes. Humanitarian organisations such as UNHCR which have a need to focus immediately on life-saving activities, neither have the organizational culture nor historical experience in such activities, so that introducing this type of programming in 1990 was similar to the beginnings of gender programming in the early seventies in CIDA. (Interviews October 27, 1994, and Oct. 20, 1995 by email)
\end{abstract}

Given my stated research interest in policy and programs directed at women, as well as attitudes to feminism inside the organization, the Senior Coordinator made a number of related comments during our interviews. She noted that the stereotype of feminists as man-hating radicals is still pervasive among the general public, and that she as well as many other women are reluctant to associate themselves with this term "for fear of undermining our credibility, particularly in the conservative and multicultural climate of a UN organization" (Email transcript interview October 20,1995). Using feminism per se in a climate adulterated with mainly negative connotations of the concept would not be constructive, she argued.

The UN High Commissioner, Dr. Sadako Ogata, and UNHCR management generally see the development of policies and guidelines on gender issues as short-term activities. The implementation of such policies and guidelines, which require attitudinal and organizational change, is a much longer term activity, the complexity of which is not yet clearly understood throughout UNHCR. The Senior Coordinator points out that:

introducing gender concerns is not like introducing technical changes in the way we deliver water and sanitation programmes, for example. They require consensus building, awareness raising, and organisational commitment. This is a message which is starting to permeate UNHCR and indeed the UN generally as underlined in the recent Joint Inspection Unit Report on implementing gender issues in multilateral organisations. (Email transcript interview October 20, 1995).

The post of Senior Coordinator for Refugee Women was set up at the request of the Canadian Government and funded by CIDA for the first two years after which UNHCR began funding the position which remains only temporary. The International Working Group on Refugee Women (IWGRW), a coalition of NGOs, has been lobbying UNHCR to make the position permanent and to upgrade its importance within the organizational structure.

UNHCR's commitment to gender analysis and community planning processes is uncertain. As the Senior Coordinator notes:

... one of the key issues ... is implementation of policy. We have a policy, but we have no way of ensuring that people respond to that 
policy. I have no way of holding people accountable for not implementing the policy ... That's a major barrier ... and one which is acknowledged (ibid.).

Implementation of policies promoting women at UNHCR headquarters in Geneva is clearly challenging. Translating these for the field and implementing change in refugee camps is just as difficult. The initiative outlined below blends issues of representation, cultural and gender differences, and organizational politics at one location where three refugee camps host over 100,000 refugees. It responds to the questions posed at the outset: "is a refugee camp a community or an institution, and what are the gender implications for refugees?"

\section{A New Initiative: Refugee Self- Management}

"Refugee (or community) self-management" is a bold if imperfect initiative which aims to forge accountability links between donors who fund refugee agencies, the agencies that assist refugees, and the refugees themselves. Its innovation lies partly in the fact that it was developed on the ground by an NGO for a particular refugee situation and was initiated in response to a questioning of agency authority to determine refugee needs. In northeast Kenya (see map), UNHCR, CARE, and refugee leaders in three camps have collaborated to introduce this community-based approach to political process and structure. The proposal, however, has been met with some resistance. Much debate as well as disagreement has been generated among UNHCR staff at the administering suboffice in Dadaab because of its proposed redistribution of power. A brief discussion of this initiative and a sketch of competing professional approaches at work in this small, fieldbased office provide a context in which to address the question at hand.

The idea of Refugee Self-Management was developed by a senior employee of CARE, the agency responsible for much of the face-to-face contact with refugees, and day-to-day operations in the camps. CARE Canada, known as CARE International in Kenya, is the main implementing partner in the camps whose job it is to provide various services to refugees, including food distribution, outreach community support, education, and social services. CARE distributes food to refugees, assists all vulnerable groups including disabled and orphaned refugees, provides basic education programs for adults and children, and is responsible for social services and camp management generally. These services are subcontracted to CARE by UNHCR, UNHCR and its donors being the funders of CARE activities in these camps.

In the fall of 1994, the CARE staff member responsible circulated an overview of the project. It proposed that decision-making power concerning refugees and camp affairs be transferred to democratically elected groups of representatives from among the refugee community. The concept of a unitary, single community in this instance undermines the heterogeneity in the camps in which several nationalities and subclans of Somalis and their various interests are represented. As well, democratic elections-in contrast to cultural systems in which elders exert legitimate authority-are very much derived from liberal Western concepts of justice.

The proposal outlines a sharing of responsibilities through a parallel structure whereby refugee representatives decide how to spend available funds for social, economic, and infrastructural development in the camps while relief agencies, responsible to their donors and to the refugees provide these goods and services as decided upon by the refugees.

The new structure will make the refugee responsible to manage its [sic] own affairs. CARE will play the role of a necessary bridge between the donor and the refugee in controlling the resources and ensuring that they are used for their intended purposes ... The new approach would make the leadership of the community accountable to the community.
Activities and programmes would be identified, planned, and implemented through community participation exercises. (CARE 1994, 2)

Responses to CARE's proposal during the months of my research visit were mixed and measured. "We have a triangle of responsibility," argues the UNHCR Head of Sub-Office in Dadaab. "There is UNCHR which looks after the political decisions and operations; it is responsible for peacekeeping and controlling the political games in the camps. NGOs provide resources and services, and the Government of Kenya (GOK) simply provides security." In his mind, UNHCR is effectively the governing body of the three camps: "We have succeeded in breaking up the traditional structures of power (in the camps)."

Refugee self-management is viewed by some senior staff as dangerous because it poses the possibility of reviving traditional power among refugees and reinscribing elders' enclaves of autocratic authority.

Another UNHCR staff member who is responsible for collaborating on this initiative with CARE staff is predictably more supportive of the idea: "Refugees are part of a culture that has learned to be dependent and we taught them that." She hesitantly uses the analogy of wild animals tamed and then unable to survive in the wild later on. While admittedly simplistic, her main point is that refugee camps produce refugee behaviours. Her argument echoes that of other critics of dependency among refugees (Kibreab 1993), namely that there is nothing intrinsically dependent or impoverished about this culture at the "pre-refugee" stage.

Arguing against the idea of refugee self-management is one of her colleagues, a UNHCR staff member who has been a refugee himself on two occasions. He views refugees with suspicion and considers the camp "a war zone." In his view

[CARE's refugee self-management] idea may be possible in five to six years. Now deals are made to 'get' what they [refugees] want. People 
are only a 'community' for one meeting, purely for exigency. [The CARE staff person responsible for the initiative] is in a grey zone where there is room for hijacking ...

Another UNHCR staff member had only one comment about the Refugee Self-Management proposal: "How are we going to pay for it?" Her job in Dadaab is administration and finance; she too is rule-conscious but with a view to two goals: efficiency and effectiveness. UNHCR responses to CARE's proposal are important because the former effectively employs the latter organization to execute various activities, and specifies refugee programming agreed upon in various "sub-agreements" UNHCR holds with NGOs assisting refugees.

The proposal aims to redistribute decision-making power-increasing refugee participation and decreasing the role of agencies in determining priorities and projects in the camps. Two of the four personnel highlighted above fear this shift in power, a move away from UNHCR and NGO control. To placate these fears, the CARE manager in charge of the project divided so-called political power from control over economic resources in the camps. That is to say, refugees would be responsible for creating and participating in democratic decision-making structures, but material resources and funds to enact or follow through on those decisions would be provided by NGOs that would also act as a check on the fairness of decisions made. Despite this measure, some senior UNHCR staff in the camps remained opposed to the idea; the "big boss" at UNHCR in Nairobi, however, endorsed the initiative and, as of early 1995, implementation in the camps was under way.

\section{Policy versus Practice}

Iraised three criticisms of the initiative during my stay in the camps. First, in Kenya, a refugee camp is not a community. While there may be several sets of communal interest or allied refugees cooperating-organized for example among refugees of common nationality, subclan affiliation, or proximate physical location-a camp is an institution organized as a temporary solution to displacement. UNHCR has a mandate to provide material assistance and physical as well as legal protection in conjunction with the Government of Kenya (GOK). The GOK insists that refugees must reside in the camps; they are the subjects of a tacit and, I would add, unsatisfactory policy of containment. "Community" is not enforced; it does not unduly restrict the movement of its members, and it usually involves a material relationship to place through access to land, jobs, and resources whereby it can sustain itself. In Kenyan refugee camps, this is not the case. Cultural politics among the refugee, local, and humanitarian groups which share this space and among refugee factions, themselves, only complicate any power-sharing agreement or notion of a unified community. Iris Young (1990) warns that "the desire for unity or wholeness in discourse generates borders, dichotomies, and exclusions."

UNHCR policy and practices relating to "headcounts" in the camps, as one example, clearly contradict any sense of camp-as-community. UNHCR's 1994 Registration manual outlines how to manage "difficult populations" during camp censuses through the use of "enclosures" into which refugees are put in order to be counted. Both Somali and Sudanese refugees were considered "difficult" by UNHCR, and physical coercion as well as community meetings were used to conduct headcounts in 1994. Community leaders do not conduct censuses of their population by coercing, containing, and then counting their members; if anything, the subjects of Western censuses volunteer to be counted-perhaps an expression of the discipline and self-surveillance of which Michel Foucault writes. While a refugee camp is not a war zone, in my view, refugees do participate in the categories of entitlement offered to them by relief agencies in their self-interest. As Trinh T. Minh-ha succinctly says, "participate or perish" (Trinh $1990,331)$. Since headcounts are the basis for ration cards which entitle refugees to food and non-food items, it makes sense that they would maximize this entitlement by resisting counting procedures. Equally, NGOs depend on donor support and supplies which are to bejudiciously distributed. Their objective of obtaining an accurate refugee camp is also common sense, though the means of achieving this could be negotiated in other ways. The strategies of both parties, however, allude to the politics of institutions, not communities.

My second criticism is that responsibility for meaningful decision-making cannot be separated from the resources necessary to carry out decisions taken. John Tomlinson (1991) notes that the experience of many African states during the 1960 s was that they gained nominal national independence but inherited the colonial economic structures of former European administrations. If CARE and UNHCR are unwilling to relinquish any of the economic means that would enable refugee self-management to occur, they will defeat their proposed objectives and potentially (re)produce a neo-colonial power structure. As institutions, camps may also express their power in a neo-colonial, disciplinary fashion, but such problems should be addressed first by the agencies themselves, and not deferred on the pretense of giving power away.

Finally, broad participation in camp decision-making and projects-particularly by and for women-cannot be limited to the democratic structure of elected committees. During my research in the three camps, I found that much discussion revolved around "who will represent whom?" and "what will the relationship between committees be?" The majority of refugees, especially women, do not generally attend these consultations Refugee men are more likely to have the time, given the division of labour in the household and the labour-intensive female tasks required for its maintenance, as well as the language skills (i.e., English) necessary to converse with NGOs and participate in the po- 
litical process. The gendered nature of opportunity and participation are obscured in this nominally democratic process.

My research involved a series of interviews with refugee women working in their homes. Evidence was collected of their participation in informal collaborative and individual initiatives. These included collective rotating credit schemes, small solo shops set up in the camp markets, individual collection and sale of firewood, and assistance to neighbours or family who are pregnant, infirm, or elderly. Qualitative economic, social, and political differences between Bantu Somalis-Somali nationals of Tanzanian origin but non-Somali ethnicity-and Somali Somalis were also noted. Nowhere are these differences in power and status incorporated into the Refugee Self-Management proposal. These interviews reveal that (i) women have created their own community-based arrangements, outside official circuits of refugee participation; and (ii) women are largely excluded from the so-called democratic process by their gendered cultural positioning. The vast majority of Somali refugee women in these border camps are unlikely to ever be part of the official selfmanagement scheme proposed by CARE. One might argue that the refugees furthest from these centres of institutionalized power are quite capable of self-management-certainly no one is helping them at the moment. This is not to say, however, that they receive equitable treatment and material assistance relative to other refugees in the camp.

The democratic selection of leaders risks reproducing and reinscribing the power of those refugees already in positions of authority and privilege in the camps. Thus, even elections risk being an exercise in self-selection. At one meeting between refugee agencies and camp elders, the latter group submitted a list of those they unilaterally decided should be representatives, most of whom were the elders themselves; they also noted the remuneration expected. Agency staff mem- bers were dissatisfied with the elders' self-appointment; they expected that the elected refugee representatives would perform their duties without being paid.

\section{Democratic Governance in an Age of Displacement}

While partial to the idea of refugee selfgovernance based on my own background in community organization and planning, I harbour skepticism about the willingness of the aid agencies to give away any meaningful decision-making power to refugees, particularly with respect to the allocation of resources, and have reservations about how such changes might reinscribe women's subordination in the camps. Having grounded issues of political power, economic control, and gender equity in the example of the Refugee Self-Management initiative, I maintain that a refugee camp is not a community, nor is it treated as one by humanitarian agencies. To assume that principles of community development and organization are directly transferable to refugee camps is problematic. While "camps-as-communities" may be desirable, such a notion is also unrealistic. Given the contradictory actions of agencies-from headcounts to self-management-a lack of trust permeates all sides, a factor which seriously impedes meaningful power-sharing agreements.

Nonetheless, CARE's initiative recognizes that the status quo is undesirable and perhaps unacceptable. Researchers, policymakers, relief workers, and funders are becoming increasingly aware of the problems of gender-blind practices as well as the dangers of a "colonialism of compassion." A concrete first step on the part of refugee relief organizations, including the UN, is a systematic auto-critique. By this, I mean a review of the question posed at the outset by each organization, a discussion of what, if any, control over refugee operations could be shared and its rationale, as well as serious reconsideration of authority relationships in the camps.
How can refugee camps be made more democratic spaces, given the temporary nature of the solution, limited resources, and constraints imposed by host governments? One CARE manager argued that a refugee camp should be run by a voluntary board just as the NGOs are governed "at home." Perhaps there is some truth to this proposal, though replicating the structures of Western knowledges is more likely the problem than the solution. In an age of increasing displacement, the radically democratic governance of refugees in asylum countries poses a pressing challenge for donor governments, the United Nations, and NGOs alike.

\section{References}

Abu-Lughod, L. 1991. "Writing Against Culture." In Recapturing Anthropology edited by R. G. Fox, 137-62. Santa Fe: School for American Research.

African Rights. 1994. "Humanitarianism Unbound? Current Dilemmas Facing Multi-Mandate Relief Operations in Political Emergencies." Discussion paper no. 5, London, November.

Anderson, M. B., A. Brazeau, and C. A. Overholt. 1992. "People-Oriented Planning Process." UNHCR, Geneva, December.

CARE. 1994. Draft proposal on "Refugee SelfManagement." Kenya.

Gupta, A., and J. Ferguson. 1992. "Beyond 'Culture': Space, Identity, and the Politics of Difference." Cultural Anthropology 7 , no. 1 (February): 6-23.

Hyndman, J. 1996. “Geographies of Displacement: Gender, Culture, and Power in UNHCR Refugee Camps, Kenya." Unpublished PhD dissertation, University of British Columbia, Vancouver.

Kibreab, G. 1993. "The Myth of Dependency among Camp Refugees in Somalia 19791989." Journal of Refugee Studies 6, no. 4.

Mann, M. 1986. Sources of Social Power. Vol. 1. New York: Cambridge University Press.

Overholt, C. A., M. B. Anderson, K. Cloud, and J. E. Austin. 1985. Gender Roles in Development Projects: A Case Book. Hartford, CN: Kumarian Press.

Pred, A., and M. Watts. 1992. Reworking Modernity. New Jersey: Rutgers University Press.

Tomlinson, J. 1991. "The Discourse of Cultural Imperialism." In Cultural Imperialism. Baltimore: John Hopkins University Press. 
Trinh T. Minh-ha. 1990. "Cotton and Iron." In Out There: Marginalization and Contemporary $C$ ultures, edited by $\mathbf{R}$. Ferguson, $M$. Gever, Trinh T. Minh-ha, and C. West. New York: The New Museum of Contemporary Art.

UNHCR. 1994. "Criteria for selection of vulnerable groups,." Memorandum, DDB/ HCR/0457, November.

- 1993. The State of the World's Refugees: The Challenge of Protection. Toronto: Penguin.

-1993. "Making the Linkages: Protection and Assistance Policy and Programming to Benefit Refugee Women." Joint Meeting of Sub-Committees of Admin. and Financial Matters and of the Whole on International Protection. Document EC/ 1993/SC.2/crp.16, May.

-1993. "Note on Certain Aspects of Sexual Violence Against Refugee Women." Executive Committee, A/AC.96/822, October 12 .

- 1991. "Guidelines on the Protection of Refugee Women." Geneva, July.

—. 1990. "UNHCR Policy on Refugee Women." Geneva, August.

Young, I. M. 1990. "The Ideal of Community and the Politics of Difference." In Feminism/Postmodernism, edited by L. Nicholson. New York: Routledge. $\square$

\section{Refugee Rights \\ Report on a Comparative Survey}

\author{
By

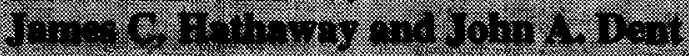

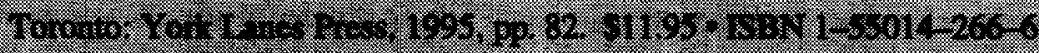

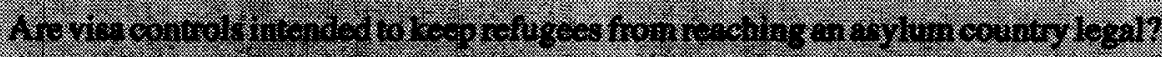

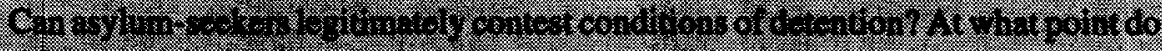

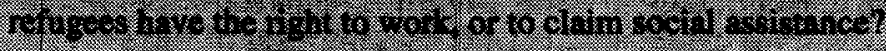

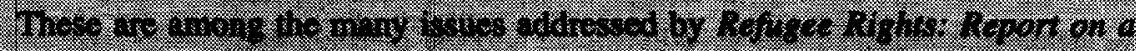

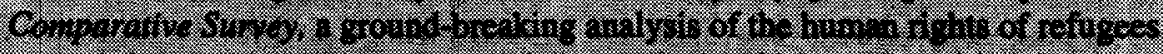

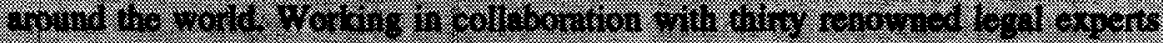

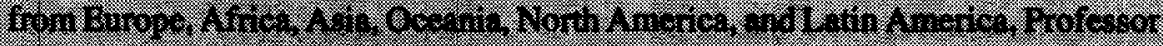

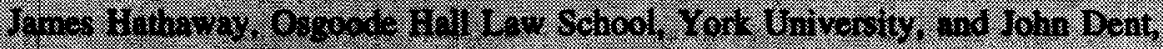

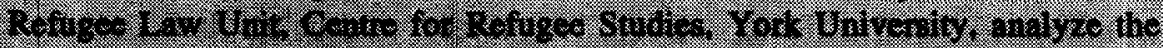

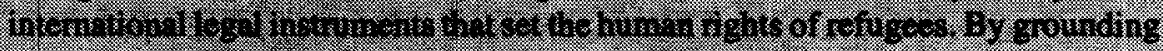

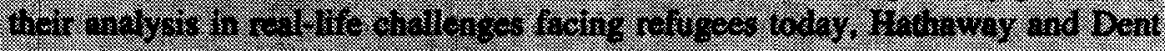

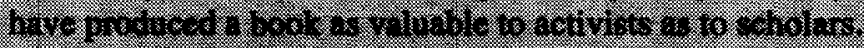

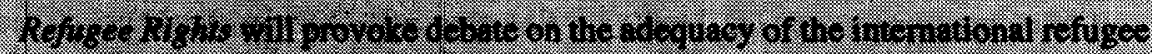

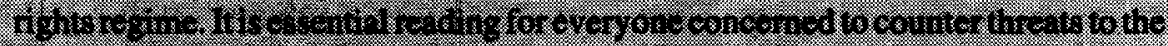

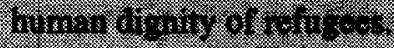

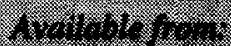

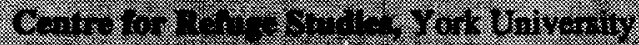

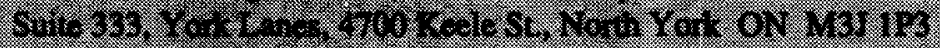

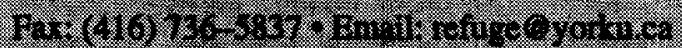

\section{From Being Uprooted to Surviving:}

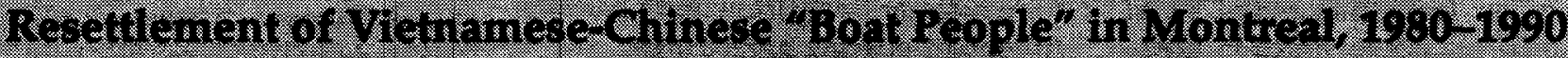

\section{By Lawerice Lim}

\section{Toronto: Yokk Lanes Press; ISBN 1-56014-296-8, 200 pages, indexed,518.95}

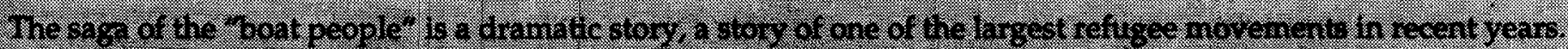

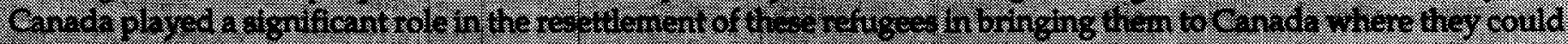
stat anc

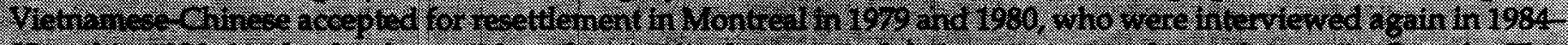

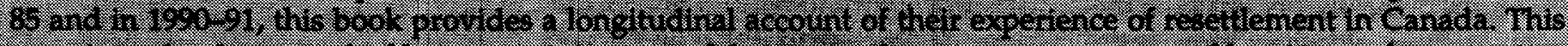

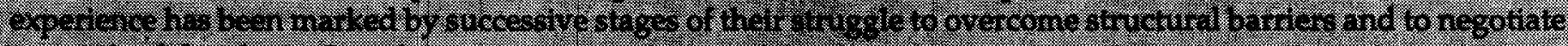
3.30 .

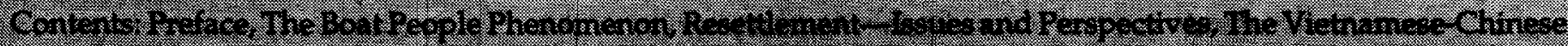

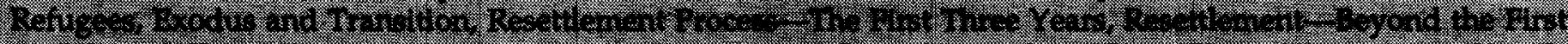
Tho.

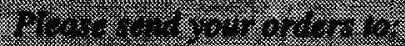

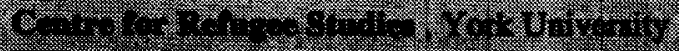

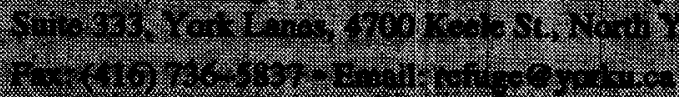

(C) Jennifer Hyndman, 1997. This open-access work is licensed under a Creative Commons Attribution-NonCommercial 4.0 International

License, which permits use, reproduction and distribution in any medium for non-commercial purposes, provided the original author(s)

are credited and the original publication in Refuge: Canada's Journal on Refugees is cited. 